\title{
Coastal drowning in Costa Rica: incident analysis and comparisons between Costa Rican nationals and foreigners
}

\author{
L. E. Segura ${ }^{1} \cdot$ I. Arozarena ${ }^{1} \cdot$ W. Koon ${ }^{2} \cdot$ A. Gutiérrez ${ }^{1}$
}

Received: 6 November 2020 / Accepted: 9 August 2021 / Published online: 25 August 2021

(c) The Author(s), under exclusive licence to Springer Nature B.V. 2021

\begin{abstract}
International and domestic tourism is a growing industry in Costa Rica, with the most attractive places located along the coast. Despite their beauty, Costa Rican beaches can pose a high risk for foreign visitors: Drowning is the primary cause of unintentional death among international visitors. This study presents a comprehensive analysis of demographics, spatial and temporal trends of national and foreigner fatal drowning occurring at Costa Rican beaches during 2001-2019. For national beachgoers, teens and young male adults, ages 15-30 years are at greatest risk of drowning, while for foreigners, older adults ages 45-60 years exhibit higher risk. Temporal trends in drowning appear to be correlated with the number of beach visitors, which seem to be driven mainly by a combination of socioeconomical and climatic/weather factors. For instance, strong economic indicators for the Costa Rican population combined with good weather fostered during warm phases of El Niño Southern Oscillation attract more national beachgoers, which may increase the number of drowning deaths. These results will help authorities better understand the complex and dynamic drowning situation to develop better prevention strategies and policies that improve beach safety and raise awareness about coastal hazards and risk. Such actions will bolster the reputation of Costa Rica as a safe touristic destination.
\end{abstract}

Keywords Drowning $\cdot$ Beach hazard $\cdot$ Tourism management $\cdot$ Costa Rica

\section{Introduction}

Prior to recent global challenges and restrictions related to COVID-19, the tourism industry was considered to be increasing worldwide as more people afforded travel within their country and abroad (UNWTO 2020). Tourism in Costa Rica, a country of five million residents, represents the largest source of national income driven by nearly three million

I. Arozarena

iarozarena@gmail.com

1 Departamento de Física, Campus Omar Dengo, Universidad Nacional de Costa Rica, Avenida 1, Calle 9, Heredia 86-3000, Costa Rica

2 School of Biological, Earth and Environmental Sciences, University of New South Wales, Sydney, Australia 
international visitors per year (Instituto Costarricense de Turismo 2018). With pristine Pacific and Caribbean coastlines, many national parks and overall good safety indicators, Costa Rica has solidified itself as a world class tourist destination in Latin America and is particularly well known for its beaches.

Most international visitors in Costa Rica visit the coast, (Instituto Costarricense de Turismo 2019b), which has accelerated real estate and economic development in these areas (Van Noorloos 2013). The increase in both international and national coastal tourism also implies greater human exposure to coastal hazards that result in both fatal and non-fatal injuries and/or drowning. Indeed, drowning is the leading cause of unintentional death among foreigners and second among nationals (Poder Judicial 2018). Between 2002 and 2012, an average of 50 fatal drowning events per year were recorded on Costa Rican beaches (Arozarena et al. 2015), a relatively high number compared to annual averages in more populous countries such as the USA, Turkey and Australia (100, 50 and 30 fatal beach drowning events, respectively; Barlas and Beji 2016; SLSA 2019; Gensini and Ashley 2009).

Previous work has shown that international beachgoers may be more at risk of drowning than residents due to their unfamiliarity with local hazards and risks (Wilks 2017; Wilks et al. 2003), language barriers and an overall relaxed attitude to safety while on holidays (Arozarena et al. 2018; Wilks 2017; Williamson et al. 2012). This attitude, aptly named "tourist brain," (Houser 2019) can also increase the consumption of alcohol during aquatic activities (Guse et al. 2007). American citizens are up to 40 times more likely to drown overseas than in the USA, with alcohol increasing that risk (Guse et al. 2007). In general, despite their significance, analysis of international tourist drowning statistics is scarce in the literature. While in Australia, international visitors represent about 5\% of drowning deaths (Peden et al. 2016) annually in Costa Rica, foreigners represented more than $30 \%$ of drowning fatalities (study period: 2002-2012) with American visitors constituting the largest group (Arozarena et al. 2015).

Although foreigners represent a large proportion of Costa Rican drowning statistics, the approach to reduce these drowning death events has been limited. The Costa Rican Tourism Bureau (ICT: Instituto Costarricense de Turismo), the main agency charged with managing tourism issues, has relied on beach hazard signage (e.g., rip currents) as a primary method to maintain people's safety. However, the effectiveness of signage is limited: Multiple studies have demonstrated that beachgoers generally do not pay attention to signs (Arozarena et al. 2018; Brannstrom et al. 2015; Wilks 2017) and find it difficult to translate and understand image representations of beach hazards (e.g., drawing of a rip current; Brannstrom et al. 2014; Ménard et al. 2018). In contrast, the presence of lifeguards at beaches is frequently recommended in the literature (Koon et al. 2021) and considered to be one of the most effective strategies to reduce drowning risk (Gilchrist and Branche 2016; Ramos et al. 2015; Wilks 2017). In 2019, the Costa Rican National Assembly passed a bill requiring coastal counties to provide permanent professional lifeguards at the most popular beaches; however, implementation of the law was significantly delayed due to COVID-19. Also, a pilot program started in January 2020 deployed permanent lifeguards in six popular beaches at Costa Rica and has generated positive initial indicators including rescues and preventive actions (ICT and Cruz Roja de Costa Rica 2019).

Previous analysis found variation in demographic characteristics and spatiotemporal trends between national and foreigner fatal beach drowning events in Costa Rica (Arozarena et al. 2015). Specifically, Arozarena et al. (2015) identified differences in seasonal trends and the locations of where Costa Rican nationals and foreigners died by drowning, information that could inform more effective and targeted prevention interventions 
and the allocation of resources. Drowning prevention and beach safety interventions that prioritize a specific population are likely to be more effective compared to a one-size-fits all approach. To better inform future prevention efforts, our aim was to further characterize the differences in fatal drowning trends of Costa Ricans and foreigners by evaluating seven additional years (2013-2019, in respect to Arozarena 2015) of time series data, with a focus to identify geographic areas of increased incidence. These results will ultimately contribute reducing the occurrence and burden of drowning at Costa Rican beaches.

\section{Methodology}

\subsection{Study area}

Costa Rica exhibits approximately 640 beaches spanning over $1200 \mathrm{~km}$ of coastline which is shared among three coastal provinces: Guanacaste and Puntarenas at the Pacific side and Limón facing the Caribbean Sea (Fig. 1). The Pacific coast is more irregular and rocky than the Caribbean coast, showing several peninsulas, bays and pocket beaches featuring parallel and rhythmic sand bars and strong rip currents. Moreover, the Pacific coast experiences a more energetic wave climate and has a larger tidal range $(>2 \mathrm{~m})$ than the Caribbean (<1 m) (Lizano 2003, 2007; Gutiérrez-Echeverría Soley-Alfaro 1988). The most

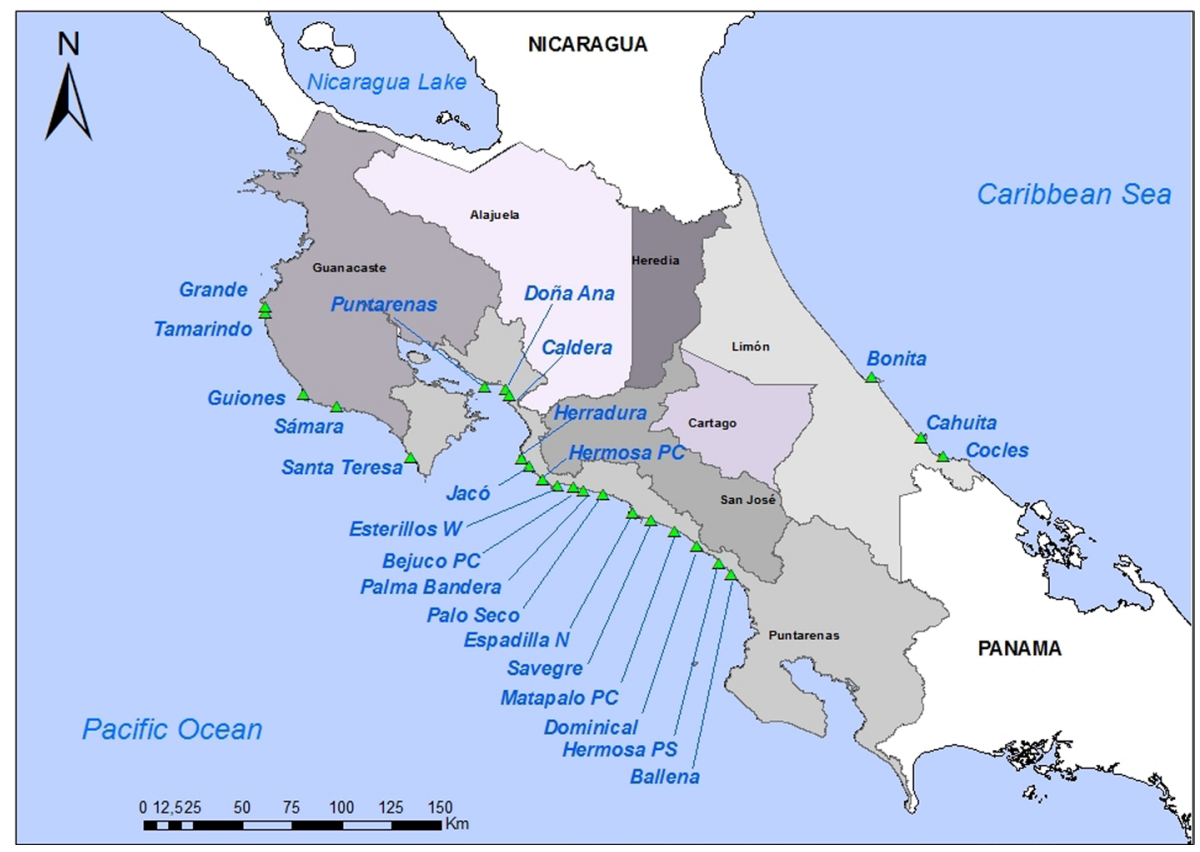

Fig. 1 Map of Costa Rica showing the political limits of the provinces and the locations of the 24 beaches that accounted for 50\% of drowning deaths (period 2001-2019). These locations will be analyzed latter in the paper 
visited beaches are located along the Central Pacific coast (Jacó, Hermosa PC, Espadilla, Ballena) as they are the closest to San José, the capital (see Fig. 1).

\subsection{Data sources and analysis}

The Costa Rican Judicial Investigation Department (OIJ: Organismo de Investigación Judicial) is a branch of the federal court system which investigates all unintentional deaths occurring in Costa Rica. The Statistics Section of OIJ maintains a robust database of such events with information provided by the Department of Forensic Sciences (DFS), which has incorporated information on unintentional drowning deaths since 2001. Cases from this database used in this analysis are unintentional drowning death events (e.g., not homicides or suicides) that occurred in coastal areas where the primary cause of death was registered as submersion asphyxia by DFS-OIJ. For this analysis, we evaluated all unintentional drowning deaths occurring on beaches from 2001 to 2019. The database and subsequent analysis include the following variables: age, gender, civil/marital status, nationality, time and date and geographic location. Civil status includes several levels: single, married, de facto, divorced and widowed, which we reduced to two levels: married (which includes de facto) and single (including the rest). Nationality is determined and recorded by the OIJ agent at the time of identification of the body. Location information such as province, county, district and beach where the drowning death occurred is also registered. In 2001 and 2003, the civil status was not recorded and thus, there are 157 events (17\%) without these data. In addition, the 68 (7\%) events which occurred in 2002 lack incident location and there are $17(1.8 \%)$ events without nationality.

We calculated descriptive statistics and conducted independent sample t tests to assess for demographic differences in age, civil status and gender between nationals and foreigners, stratified by province where the drowning death occurred. In addition, we assessed for time trends in drowning events for nationals and foreigners. We conducted a subanalysis at the beach level for the 24 beaches that accounted for $50 \%$ of drowning incidents in the study period, assessing for trends by beach and country of origin.

Cumulative drowning rates per 100,000 visitors for the study period 2001-2019 were estimated using data from Costa Rican Tourism Bureau of overseas visitors entering the country by airport and that spent less than three months in Costa Rica. Following Wilks et al. (Wilks et al. 2003), the rate was calculated by dividing the drowning death events averaged over 2001-2019 by the average number of visitors that entered the country for the same period. Similarly, for nationals, the drowning rate was calculated using the population in Costa Rica over 2001-2019 (Programa Estado de la Nación 2019).

All analyses were conducted using R Studio V4.0.1 (R Core Team 2019). Data used in this study, collected and maintained by OIJ, are publicly available; ethics approval was not required for this study as the analysis of de-identified data previously collected for administrative purposes does not meet the definition of human subjects research by the Universidad Nacional de Costa Rica.

\section{Results}

From 2001 to 2019, 936 people died from drowning in Costa Rica. While most decedents $(62 \%, n=580)$ were nationals, foreigners (from 36 different countries) comprised a substantial proportion $(38 \%, n=356)$. Males represented the majority of decedents for both 
nationals and foreigners, 92 and $86 \%$ respectively. Nearly half $(45 \%, n=264)$ of national decedents were aged between 15 and 30 years old, while a much lower percentage (15\%, $n=88$ ) belonged to older ages (45-60 years old). In contrast, for foreigners, the 45-60 age category was most frequent $(31 \%, n=109)$ followed by the $15-30$ category $(26 \%, n=92)$. The mean age of national drowned decedents was statistically lower than that of foreigners (Table 1). No statistical age differences were found in between men and women in either the national or foreigner groups (Table 1). For civil status, single decedent mean age was statistically lower than married ones for both nationals and foreigners. Guanacaste exhibited the oldest decedents for both groups, followed by Limon and Puntarenas (Table 1).

Most drowning deaths for nationals and foreigners (70 and 62\%, respectively) took place at Puntarenas followed by Guanacaste (18 and 22\%) and Limon (12 and 16\%). Most of the drowning death events involving nationals occurred during weekends and January and April, while for foreigners, events occurred mainly on Sundays and in March and July (Fig. 2a-b). The annual drowning trend for each province showed different patterns for both nationals and foreigners, especially in Puntarenas and Guanacaste (Fig. 2c). Drowning deaths among nationals decreased from 2001 to 2007 at Puntarenas but increased in Guanacaste during the same period. In contrast, from 2007 to 2013, there was an overall reduction in drowning deaths at both provinces for nationals, followed by an increment of one per year at Guanacaste during 2013-2018 (Fig. 2c).

For foreigners, there was a steady increase in drowning death cases that took place in Guanacaste during 2001-2019 and also at Puntarenas during 2014-2018, where it

Table 1 Descriptive statistics (mean, median, standard deviation) and t-statistics (p value and 95\% confidence intervals for the mean age difference) of age separated by gender, nationality, civil status and province

\begin{tabular}{|c|c|c|c|c|c|c|c|c|}
\hline \multirow{2}{*}{$\begin{array}{l}\text { Age differ- } \\
\text { ence by }\end{array}$} & & & \multirow[t]{2}{*}{$N$} & \multirow[t]{2}{*}{ Mean age } & \multirow[t]{2}{*}{ Median age } & \multirow{2}{*}{$\begin{array}{l}\text { Standard } \\
\text { devia- } \\
\text { tion }\end{array}$} & \multicolumn{2}{|c|}{ T-Statistics } \\
\hline & & & & & & & $P$ value & $\begin{array}{l}95 \% \text { Confi- } \\
\text { dence interval } \\
\text { of mean dif- } \\
\text { ference }\end{array}$ \\
\hline \multirow[t]{2}{*}{ Nationality } & & Nationals & 580 & 31 & 27 & 17.5 & \multicolumn{2}{|c|}{$<0.001[11.1,15.7]$} \\
\hline & & Foreigners & 356 & 45 & 46 & 16.6 & & \\
\hline \multirow[t]{4}{*}{ Gender } & \multirow[t]{2}{*}{ Nationals } & Male & 532 & 31 & 27 & 16.3 & \multirow{2}{*}{\multicolumn{2}{|c|}{$0.23[-2.3,9.2]$}} \\
\hline & & Female & 48 & 28 & 22.5 & 19.0 & & \\
\hline & \multirow[t]{2}{*}{ Foreigners } & Male & 306 & 45 & 45.5 & 17.3 & \multirow{2}{*}{\multicolumn{2}{|c|}{$0.57 \quad[-3.9,7.1]$}} \\
\hline & & Female & 50 & 43 & 46 & 18.3 & & \\
\hline \multirow[t]{4}{*}{ Civil status } & \multirow[t]{2}{*}{ Nationals } & Married & 153 & 46 & 46 & 12.7 & \multirow{2}{*}{\multicolumn{2}{|c|}{$<0.001[18.2,23.2]$}} \\
\hline & & Single & 334 & 25 & 21 & 13.6 & & \\
\hline & \multirow[t]{2}{*}{ Foreigners } & Married & 147 & 53 & 54 & 13.1 & \multirow{2}{*}{\multicolumn{2}{|c|}{$<0.001[13.2,20.3]$}} \\
\hline & & Single & 145 & 36 & 32 & 17.5 & & \\
\hline \multirow[t]{6}{*}{ Province } & \multirow[t]{2}{*}{ Puntarenas } & Nationals & 398 & 30.0 & 26 & 16.5 & \multirow{2}{*}{\multicolumn{2}{|c|}{$<0.001[8.8,14.3]$}} \\
\hline & & Foreigners & 215 & 41.5 & 41 & 16.5 & & \\
\hline & \multirow[t]{2}{*}{ Guanacaste } & Nationals & 107 & 35.2 & 32 & 17.6 & \multirow{2}{*}{\multicolumn{2}{|c|}{$<0.001[13.4,23.5]$}} \\
\hline & & Foreigners & 83 & 53.6 & 56 & 16.6 & & \\
\hline & \multirow[t]{2}{*}{ Limon } & Nationals & 75 & 31.1 & 26 & 16.0 & \multirow{2}{*}{\multicolumn{2}{|c|}{$<0.001[31.0,43.0]$}} \\
\hline & & Foreigners & 58 & 43.1 & 44.5 & 16.8 & & \\
\hline
\end{tabular}



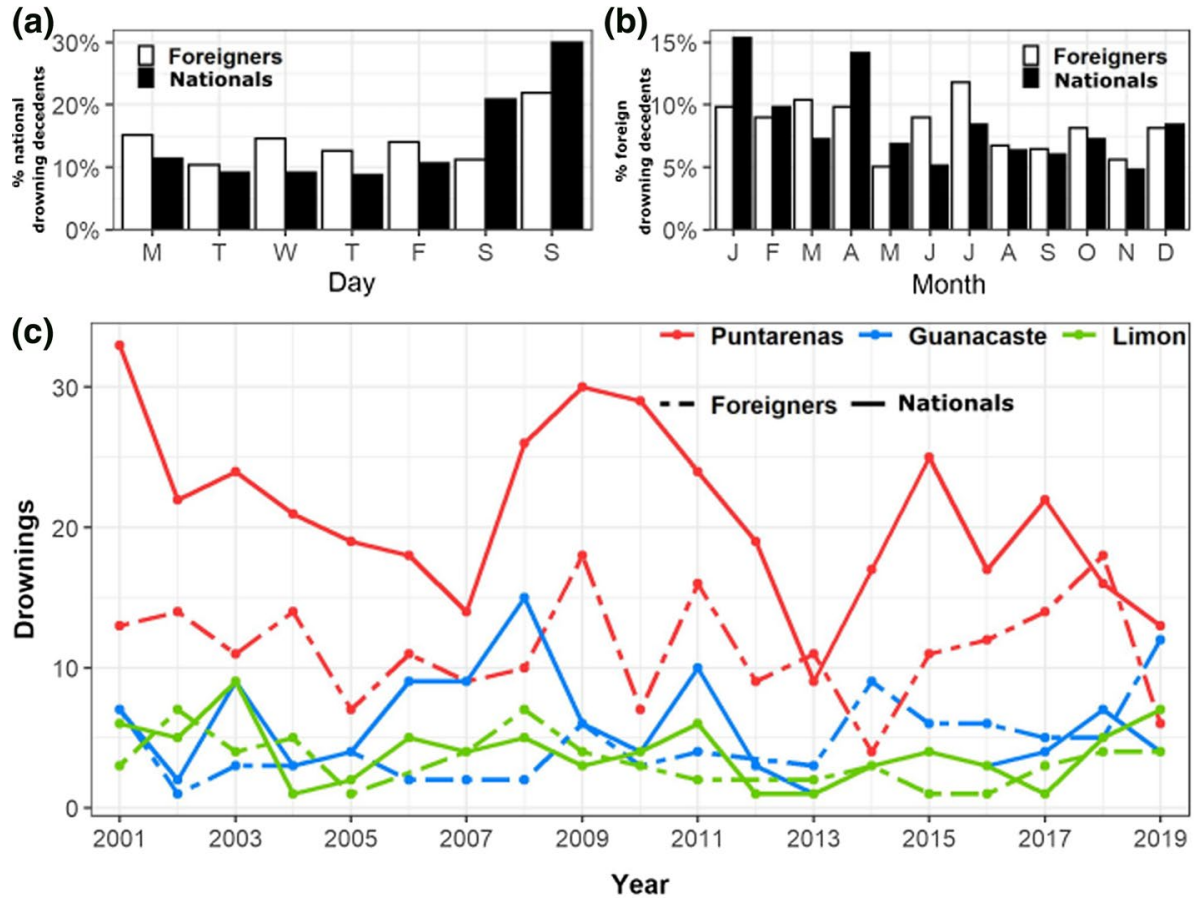

Fig. 2 a Percentage of national and foreigner drowning decedents per day of the week; b Percentage of national and foreigner drowning decedents per month; c) Time series of fatal drowning events separated by province for foreigners (dashed lines) and nationals (solid lines)

shows an increase of approximately three deaths per year resulting in more drowning fatalities involving foreigners by 2018 at this province. In Limón, the trend for fatalities among both nationals and foreigners exhibited an oscillatory pattern for the study period (Fig. 2c).

The majority of drowning deaths for nationals and, at times, for foreigners were concentrated in Puntarenas, especially at beaches located on the central Pacific coast including Jacó, Esterillos West, Hermosa, Bejuco PC and Palo Seco (Fig. 3; see Fig. 1 for map). In Guanacaste, pre-2011 drowning deaths involved mostly nationals while post-2011 events involved mostly foreigners. At the Caribbean coast, drowning fatalities decreased after 2008, especially for foreigners, but started to increase from 2017 for nationals.

During the period 2001-2019 those from the USA constituted the largest proportion of foreign drowning deaths $(40 \%, n=142)$, followed by Europeans $(19 \%, n=66$; from which one fourth where from Germany), Nicaraguans (16\%, $n=57)$, Canadians $(n=8 \%, n=28)$ and people coming from other Latin American and Asian countries (8\%, $n=29$ and 5\%, $n=16$, respectively). The relative proportions of these geographic groups varied for each beach (Fig. 4b). Drowning deaths involving people from the USA primarily occurred on the Central and North Pacific beaches (except for Jacó). Foreigners from Nicaragua constituted the largest percentage of foreign drowning deaths at the beaches of Puntarenas and Caldera (Fig. 4b). As a total, foreigners have a drowning death rate of 1.00 per 100,000 visitors, while Costa Ricans show a death rate of 0.61 per 100,000 inhabitants. 


\section{No of drowning deaths per beach $-1 \odot 3 \bigcirc 5 \bigcirc 7$}

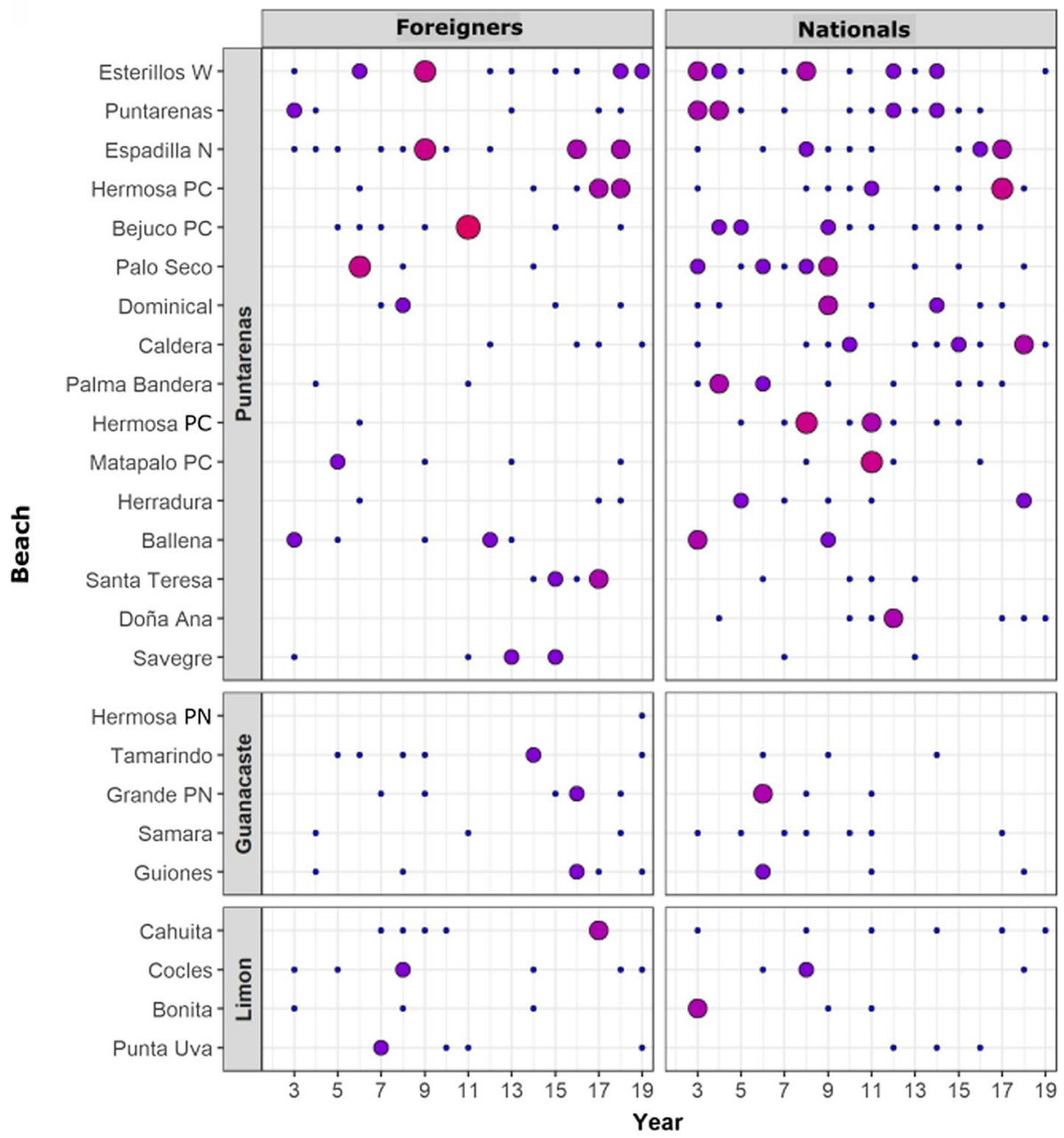

Fig. 3 The 24 beaches that accounted for 50\% of drowning deaths (period 2001-2019) separated by province. Beaches are placed in a descending order of number of total drowning deaths (nationals plus foreigners). The size and the color of the marker represent the number of drowning deaths. (PC: Central Pacific coast. PN: North Pacific coast. PS: South Pacific coast. W: West. N: North)

\section{Discussion}

In this analysis of 936 fatal beach drowning deaths in Costa Rica, we found variability in demographic characteristics and spatiotemporal occurrence between drowning events of nationals and foreigners. Costa Rican drowning fatalities tend to be single male teenagers and young adults, similar to beach drowning trends from the USA and France (Gensini and Ashley 2009; Tellier et al. 2019). Younger men and women are the dominant domestic beach users in Costa Rica and are involved in beach recreation in similar proportions (Arozarena et al. 2018). However, males dominated beach drowning statistics for nationals and 
(a)

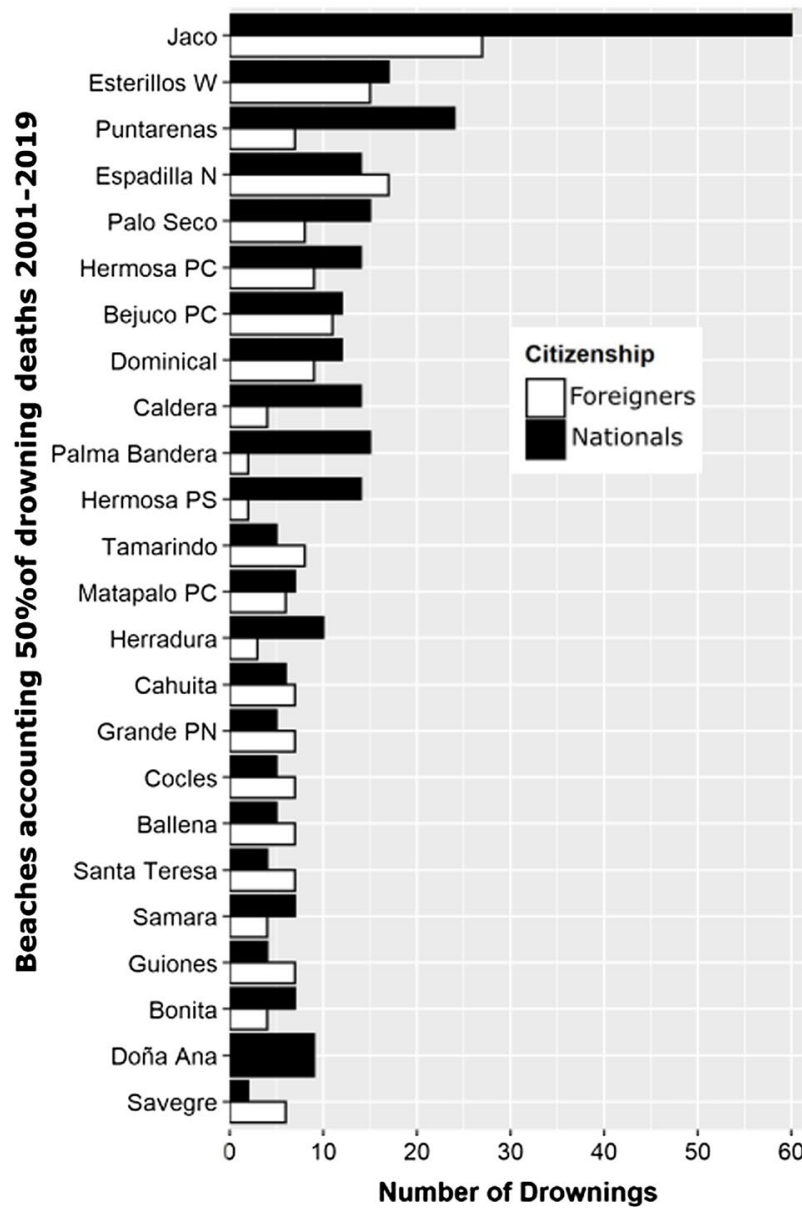

(b)

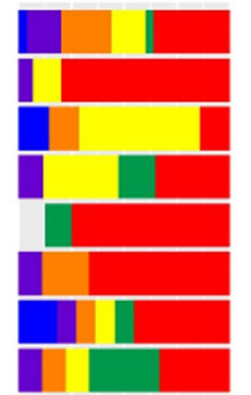

Region

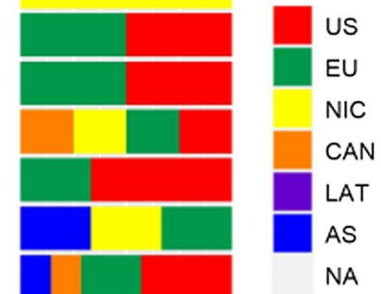

Fig. 4 a The 24 beaches that accounted for 50\% of drowning deaths (period 2001-2019 placed in a descending order of number of total drowning deaths (nationals plus foreigners). (PC: Central Pacific coast. PN: North Pacific coast. PS: South Pacific coast. W: West. N: North). Color indicates the proportion of Costa Rican (white) and Foreigners (black). b Percentages of each region of origin per beach (USA: United States of America, CAN: Canada, NIC: Nicaragua, LA: Latin America, EU: Europe, AS: Asia)

foreigners similar to other countries (Gensini and Ashley 2009; Woodward 2015; Tellier et al. 2019; Lawes et al. 2020). This fact has been attributed to the tendency for men, compared to women, to overestimate their own swimming skills, underestimate risk or their own vulnerability, and to increased exposure to water activities (Arozarena et al. 2018; Moran 2011; Willcox-Pidgeon et al. 2018; Woodward 2015; Lawes et al. 2020). Thus, Costa Rican single male teenagers and young adults are a high-risk population at beaches.

In contrast, foreigners who fatally drowned tended to be older than Costa Ricans who died from drowning, especially in Guanacaste where most deaths were 45-60 years old (Table 1). Guanacaste's airport receives an average of $10 \%$ more visitors aged $45+$ compared to other airports in Costa Rica (Instituto Costarricense de Turismo 2019b), and Guanacaste is a popular spot for relocating foreign retirees (Van Noorloos 2011, 2013). 
This suggests that an older foreign population is more predominant in this province which is reflected in its drowning demographic profile. Observations of injuries of US citizens traveling abroad demonstrate that the likelihood of drowning overseas greatly increases with age (Guse et al. 2007) further emphasizing the increased vulnerability of older people.

Our results show that foreigners exhibit more risk of drowning than nationals (drowning rate of 1.00 per 100,000 compared to 0.60), similar with studies at other locations (Guse et al. 2007; Peden et al. 2016; Wilks et al. 2003). This situation is likely related to unfamiliarity with the beach environment and its hazards, health issues related to aging and an aptitude that underestimates threats during holidays (Arozarena et al. 2018; Guse et al. 2007; Wilks 2017).

At a provincial scale, the inter-annual trends in number of drowning incidents over the study period (Fig. 2c) may be largely governed by societal, economic and meteorological factors that dictate beach user preferences, especially on the Pacific Coast. For Costa Ricans, the decreasing trend in drowning in Puntarenas during 2001-2007 accompanied an overall increasing trend in Guanacaste (2001-08), presumably attributed to a change in holiday destinations for domestic tourism as Guanacaste's resorts rapidly developed during that period. Guanacaste's tourist industry and real estate experienced record growth between 2001 and 08 which tripled new construction in the area (Instituto Costarricese de Turismo 2007; Van Noorloos 2013) and increased tourist accommodation by 50\%, compared to just $4 \%$ in Puntarenas over the same period (Chenk Mok 2014). Likewise, the subsequent reduction in domestic drowning deaths over 2009-13 at Guanacaste and Puntarenas might have been a consequence of a reduction in beach visitors. Tourist accommodation occupancy rates fell rapidly from 2011 in these provinces (Instituto Costarricense de Turismo, 2019a; Vindas 2013), despite continued expansion of the tourism industry nationally (Chenk Mok 2014; Instituto Costarricense de Turismo 2019a). By 2013, occupancy rates were the lowest of the study period, coinciding with the least number of annual drowning events in Puntarenas and Guanacaste.

Decreased Costa Rican beach visitation from 2009 to 2013 is likely related to an economic crisis during those years which resulted in increased unemployment, cost of living and poverty (Programa Estado de la Nación, 2019). Similarly, but at an international scale, the 2008-global financial crisis likely influenced the deceleration in number of foreigners visiting Costa Rica in the following years (Instituto Costarricense de Turismo 2019a). It is possible that reduction in foreigner drowning deaths at the Pacific Coast observed over the period 2009-13 is due to the impact of both local and global economic downturns, and limited efforts to prevent beach drowning deaths during this time.

Meteorological conditions also affect the number of beachgoers, who in general prefer sunnier and hotter days (Castelle et al. 2019). On the Costa Rican Pacific Coast, these conditions are exacerbated during the onset of the warmer phase of El Niño-Southern Oscillation (ENSO; Instituto Meteorológico Nacional 2020) causing a reduction in rainfall and frequency, and an increase in ambient temperatures along Puntarenas and Guanacaste (Wayle et al. 1996; Waylen and Sadí, 1999). During 2014-16, a drier and hotter climate was triggered by a strong warm ENSO event which produced one of the worst droughts ever registered in the region (Instituto Meteorológico Nacional 2020; La Nación, 2015). These favorable weather conditions (more frequent hot and sunny days) together with rebounding international tourism likely increased beach attendance as reflected by the recovery in hotel occupancy rates over that period (Instituto Costarricense de Turismo 2019a; Programa Estado de la Nación, 2019). Alignment of climatic and economic conditions may be related to the increased fatal drowning numbers in Guanacaste and Puntarenas in those years (Fig. 3c), consistent with observations by Castelle et al. (2019), in 
which drowning was more likely to occur on warm sunny days due to increased number of beachgoers.

Beaches in the Central Pacific districts of Jacó and Parrita represent the greatest burden of fatal beach drowning events both for Costa Ricans and foreigners (Fig. 4). Arozarena et al. (Arozarena et al. 2015) ascribed the hazard of these popular beaches to a combination of high beach attendance (nationals prefer these sites due to their proximity to the capital San Jose) (Arozarena et al. 2018), presence of rip currents and not enough lifeguards. Although signage at these sites indicate the main hazards, their effect has been recognized as limited not only in Costa Rica (Arozarena et al. 2018), but worldwide (Brannstrom et al. 2015; Ménard et al. 2018; Wilks 2017).

Future efforts to prevent drowning in Costa Rica should consider demographic trends and differences to effectively prioritize the right population with effective interventions. To foster a beach safety culture among the national population, strategies such as schoolbased aquatic safety programs or targeted messages for segments of the population, such as young single men, should be considered.

Approaches to prioritize safety among the foreign population require strong collaboration with the tourism industry, especially businesses located close to beaches. Educational programs such as brochures, posters and videos describing beach hazards and promoting safe aquatic behaviors should be tailored for the foreigner and international tourist audience and available at airports, hotels and restaurants (Wilks et al. 2005). In addition, courses in aquatic safety and beach hazards could be provided to people working with international visitors such as hotel managers, tour guides and even the drivers of tourist vehicles.

Principally, a strong national lifeguarding system which guarantees permanent and professional supervision, prevention and rescue services at beaches is required. Importantly, the sustainability and success of any lifeguard system in the country will require support from local, provincial and central government, in addition to that of the tourism industry. Lifeguards can also help in reporting variables (Koon et al. 2020) that the existing drowning database lacks such as the exact time and location where the event occurs. Timestamped and geographic information on incidents allows for a plethora of other data linkage opportunities, including climate and ocean variables (e.g., wind speed, wave height, tide) and the exact cause of the drowning death (e.g., rip currents, high waves). Not only would this information improve understanding of the climatic variables and conditions that increase the likelihood of fatal drowning in Costa Rica but could also potentially lead to prediction and ultimately data-driven prevention of future fatalities.

\subsection{Strengths and limitations}

This study is the first of its kind to specifically examine variance between foreigners and nationals who have fatally drowned in Costa Rica. A major strength of this study is the detailed death data on which it is based, collated and maintained in a robust system by the Costa Rican government. However, for our specific study domain examining variance in drowning trends between nationals and foreigners, there are some limitations. First, OIJ fatal drowning data are based on the nationality of the decedent, not residency. It is possible that some decedents identified as foreigners were also legal residents of Costa Rica at the time of death, which is a limitation of the recording system. Moreover, ICT visitation data are based on the residence or citizenship, so comparisons and calculated rates using both OIJ and ICT data sources should be noted with caution. Additionally, not all visitors arriving to Costa Rica go to the beach, and the distribution of both national and foreigner 
visitors among the different beaches around the country remains unknown. Actual beach visitation data would better approximate exposure and risk and improve the strength of analyses such as this.

\section{Conclusions}

Clear demographic and geographic differences exist between national and foreigner drowning events in Costa Rica resulting in two distinct at-risk populations: young males and teens (15-30 years old) for nationals and older males (45-60) for foreigners. These insights provide both government and non-government actors responsible for drowning prevention and beach safety an evidence-based foundation to prioritize prevention efforts. Future interventions addressing these at-risk populations should be designed and implemented with consultation from members of these groups and must be evaluated to assess their effectiveness and impact.

Acknowledgements The authors would like to dedicate this work to Dr. Laura Segura, who unexpectedly passed away before this work was published. She dedicated the last months of her life to working on this paper, and managing a detailed rip current study of the six most deadly beaches in Costa Rica. We will always remember her as an excellent scientist, better colleague and amazing person. Costa Rica has a better understanding of rip current deaths thanks to her work. We would also like to thank the Office of Statistics of the Costa Rican Judicial Investigation Department and the Costar Rican Touristic Bureau who kindly provided the database of drowning deaths, and the information about international visitors, respectively.

Funding This research was supported by the project "Instituto Internacional del Océano" from the Department of Physics, Universidad Nacional de Costa Rica.

Availability of data and material Available upon request to the corresponding author.

\section{Declarations}

Conflict of interest The authors declare no competing financial interests or non-financial interests.

\section{References}

Arozarena I, Gutiérrez A, Trimble S, Brannstrom C, Houser C (2018) Determining beach user knowledge of rip currents in Costa Rica. J Coastal Res 34(5):1105-1115. https://doi.org/10.2112/JCOAS TRES-D-17-00131.1

Arozarena I, Houser C, Gutie A, Brannstrom C (2015) The rip current hazard in Costa Rica. Nat Hazards 77(2):753-768. https://doi.org/10.1007/s11069-015-1626-9

Barlas B, Beji S (2016) Rip current fatalities on the Black Sea beaches of Istanbul and effects of cultural aspects in shaping the incidents. Nat Hazards 80:811-821

Brannstrom C, Lee Brown H, Houser C, Trimble S, Santos A (2015) "You can't see them from sitting here": Evaluating beach user understanding of a rip current warning sign. Appl Geogr 56:61-70. https://doi. org/10.1016/j.apgeog.2014.10.011

Brannstrom C, Trimble S, Santos A, Brown HL, Houser C (2014) Perception of the rip current hazard on Galveston Island and North Padre Island, Texas, USA. Nat Hazards 72(2):1123-1138. https://doi.org/ 10.1007/s11069-014-1061-3

Castelle B, Scott T, Brander R, Al E (2019) Environmental controls on surf zone injuries on high-energy beaches. Nat Hazards Earth Syst Sci 19:2183-2205

Chenk Mok S (2014) Turismo en el pacífico costarrice e: un análisis de la oferta y demanda. Diálogos Rev Electr Hist 15(2):69-108 
CT, Cruz Roja de Costa Rica (2019) Cooperation agreement for the continuous surveillance of 6 beaches in Costa Rica.

Gensini VA, Ashley WS (2009) An examination of rip current ns fatalities in the United States. Nat Hazards 54(1):159-175. https://doi.org/10.1007/s11069-009-9458-0

Gilchrist J, Branche C (2016) Lifeguard effectiveness. In: Tipton WA (ed) The Science of Beach Lifeguarding. CRC Press, Florida

Guse C, Cortés L, Hargarten S, Hennes H (2007) Fatal injuries of US citizens abroad. J Travel Med 14:279-287

Gutiérrez-Echeverría A, Soley-Alfaro FJ (1988) Características del nivel del mar en los litorales costarricenses. Cienc Tecn 12(1/2):117-131

Houser C (2019) Why your tourist brain may try to drown you? In: The conversation. Available from: https://theconversation.com/why-your-tourist-brain-may-try-to-drown-you-111709

Instituto Costarricense de Turismo (2018) Cuenta Satélite de Turismo

Instituto Costarricense de Turismo (2019a) Anuarios Estadísticos 2005-2019

Instituto Costarricense de Turismo (2019b) Encuesta Aérea de $\mathrm{N}^{\mathrm{o}}$ Residentes, Aeropuerto Internacional Juan Santamaría 2008-2018

Instituto Costarricese de Turismo (2007) Unidad de planeamiento Guanacaste Norte: Plan de Uso del Suelo y Desarrollo Turístico

Instituto Meteorológico Nacional (2020) Boletín ENOS

Koon W, Schmidt A, Queiroga AC, Sempsrott J, Szpilman D, Webber J, Brander RW (2021) Need for consistent beach lifeguard data collection: results from an international survey. Inj Prev 27:308315. https://doi.org/10.1136/injuryprev-2020-043793

Koon W, Peden A, Lawes JC, Brander RW (2021) Coastal drowning: a scoping review of burden risk factors and prevention strategies. PLoS One 16(2):1-22. https://doi.org/10.1371/journal.pone. 0246034

La Nación. (2015). Sequía de 2014-2015 es la más intensa desde 1930 en Costa Rica. La Nación.

Lawes J, Ellis A, Daw S, Strasiotto L (2020) Risky business: a 15-year analysis of fatal coastal drowning of young male adults in Australia. Inj Prev Published Online First: Novemember. https://doi.org/10. 1136/injuryprev-2020-043969

Lizano, O. (2003). Técnicas de pronóstico de oleaje para las costas de Costa Rica. Centro de Investigaciones Geofísicas (CIGEFI) Universidad de Costa Rica. 49 p.

Lizano O (2007) Climatología del viento y oleaje frente a las costas de Costa Rica, parte 1. Cienc y Tecnol Rev La Univ Costa Rica 25:43-56

Ménard A, Houser C, Brander R (2018) The psychology of beach users: importance of confirmation bias, action, and intention to improving rip current safety. Nat Hazards 94:953-973

Moran K (2011) (Young) Men behaving badly: Dangerous masculinities and the risk of drowning in aquatic leisure activities. Ann Leis Res 14:260-272

Peden A, Franklin R, Legat P (2016) (2016) International travelers and unintentional fatal drowning in Australia-a 10 year review 2002-2012. J Travel Med 23:1-7

Poder Judicial (2018) Muertes Accidentales 2014-2018

Programa Estado de la Nación (2019) Estadísticas

R Core Team (2019) R: A language and environment for statistical computing. R Foundation for Statistical Computing, Vienna, Austria. Available online at https://www.R-project.org/

Ramos W, Beale A, Chambers P et al (2015) Primary and secondary drowning interventions: the american red cross circle of drowning prevention and chain of drowning survival. Int $\mathrm{J}$ Aquat Res Educ $9: 8$

Surf Lifesaving Australia [SLSA]. (2019) National Coastal Safety Report. SLSA: Sydeny. Available from: https://issuu.com/surflifesavingaustralia/docs/ncsr2019 pp 40-49.

Tellier É, Simonnet B, Gil-Jardiné C, Al E (2019) Characteristics of drowning victims in a surf environment: a 6-year retrospective study in southwestern France. Inj Epidemiol 6:1-9

UNWTO. (2020). Global and Regional Tourism Performance.pp 1-9. https://www.unwto.org/es/globaland-regional-tourism-performance

Van Noorloos F (2011) Residential tourism causing land privatization and alienation: new pressures on Costa Rica's coasts. Dev 54(1):85-90

Van Noorloos F (2013) Residential tourism and multiple mobilities: local citizenship and community fragmentation in Costa Rica. Sustain 5:570-589

Vindas, L. (2013). Costa Rica: Hotel Occupancy Does Not Meet Expectations. El Financiero.

Wayle P, Quesada M, Caviedes C (1996) Temporal and spatial variability of annual precipitation in Costa Rica and the southern oscillation. J Climatol 16:173-193 
Waylen P, Sadí M (1999) Flooding and the El Niño-Southern oscillation phenomenon along the Pacific coast of Costa Rica. Hydrol Process 13:2623-2638

Wilks J (2017) Tourism and auatic safety: no lifeguard on duty-Swin at your own risk. Tour Mar Environ $12: 211-219$

Wilks J, Dawes P, Pendersgast D, Williamson B (2005) Tourists and beach safety in Queensland, Australia. Tour Mar Environ 1:121-128

Wilks J, Pendergast D, Wood M (2003) Accidental deaths of overseas visitors in Australia 1997-2000. J Hosp Tour Manag 10:79-89

Willcox-Pidgeon S, Kool B, Moran K (2018) Perceptions of the risk of drowning at surf beaches among New Zealand youth. Int J Inj Contr Saf Promot 25:365-371

Williamson A, Hatfield J, Sherker S, Brander R, Hayen A (2012) A comparison of attitudes and knowledge of beach safety in Australia for beachgoers, rural residents and international tourists. Aust N Z J Public Health 36(4):385-391. https://doi.org/10.1111/j.1753-6405.2012.00888.x

Woodward, E. (2015). Rip Currents in the UK : Incident Analysis, Public Awareness , and Education. University of Plymouth. 1-275

Publisher's Note Springer Nature remains neutral with regard to jurisdictional claims in published maps and institutional affiliations. 